\title{
ДВА НЕОБХОДИМЫХ И ДОСТАТОЧНЫХ ФАКТОРА ЭКОНОМИЧЕСКОГО РАЗВИТИЯ СОВРЕМЕННОГО ОБЩЕСТВА
}

\author{
(c) 2021 Пушкарев Дмитрий Владимирович \\ кандидат экономических наук \\ преподаватель кафедры «Государственное и муниципальное управление» \\ Московский государственный институт международных отношений (университет) \\ Министерства иностранных дел Российской Федерации, Россия, Москва \\ E-mail:pdv_2003@mail.ru \\ ORCID ID: https://orcid.org/0000-0003-0862-7003
}

Предмет. В современном мире, независимо от политического строя или общественного уклада, как и прежде - существует только два фактора в полной мере подтверждающих рост экономик, и что важнее - рост благосостояния граждан. Это, во-первых, конкуренция во всех отраслях и сферах как основа повышения качества товаров и услуг при минимальных рыночных ценах, и во-вторых международный институт кредитования как неисчерпаемый источник развития производственных мощностей общества и его интеллектуального ресурса.

В данной статье, на примере стран с совершенно разным экономическим, социально-бытовым и культурным наследием и потенциалом, раскрывается сохраняющаяся, а в ряде случаев, растущая актуальность двух условий для роста экономик - конкуренция и кредит.

Цели. Целью данного исследования служит актуализация глобальных преимуществ развитого мира в социально-экономических условиях современной России. Применение в российских реалиях успешных кейсов других стран со схожими социально-бытовыми и идеологическими аспектами построения общества, с экономическим наследием плановой экономики. Корректировка точек приложения стратегического развития российской экономики на стадии развивающегося капитализма.

Методология. Данное исследование построено на официальных статданных мировых и национальных институтов права и экономики, кредитных организаций, международных информационных агентств, находящихся в свободном доступе.

Результаты. Проведен сравнительный эконометрический анализ данных по странам с развитой экономикой и странам с развивающейся экономикой, представлены выводы. Выявлены особенности, различия и сходства стран постсоциалистического наследия и капиталистических экономик. Проведена причинно-следственная связь между наличием в обществе института частного права и его отсутствием. Предложены пути решения поставленной проблемы развития современной экономики в России.

Выводы. Даже при наличие огромной внутренней ресурсной базы, но ориентированной на внутренний спрос экономике, ни одно государство не способно соперничать даже с корпорациями, не говоря уже о государственных образованиях, построенными на принципах конкуренции и финансируемых из внешних источников.

Независимо от местоположения страны, религии, национальной принадлежности людей и даже политического строя общества, два фактора устойчивого роста экономики работают одинаково успешно. Только конкуренция и внешняя кооперация в международном кредитном аспекте позволяют государствам повышать уровень своего развития без ущемления прав граждан на достойное существование.

Ключевые слова: развитие экономики, международный кредит, частное право, конкуренция, денежно-кредитная политика 
ГЛава 1. КОНКУРЕНЦИЯ - ОСНОВА КАЧЕСТВА ИЛИ ПОЧЕМУ ХОЛОДИЛЬНИК ВСЕГДА ПОБЕЖДАЕТ ТЕЛЕВИЗОР

При натуральном обмене деньги не нужны. Товары обмениваются между сторонними производителями в исключительно редких случаях. При натуральном хозяйстве подразумевается, что производство всего необходимого для жизнедеятельности человека, семьи или сообщества, производится в рамках одного хозяйства или довольно ограниченного круга хозяйствующих субъектов. Всем всего хватает, все довольны.

Исторически, с высоты пролетевших тысячелетий существования домашнего хозяйства как общественно-экономического института, а также на примере целых государств, мы видим, что такая форма производства и обмена существенно ограничивает потребление, а значит и запрос на обмен. В конечном итоге, отсутствие производственного обмена сокращает конкуренцию производителей, а также исключает специализацию производства, что ведет к деградации технологий, сокращению производства, товарному дефициту.

Яркий пример товарно-технологического обмена между молодыми Европейскими странами, которые в раннее средневековье заметно уступали Востоку в научном и технологическом плане, затем вырвавшихся на вершину технологического и научного прогресса, показывает, как сильно конкурентный обмен стимулирует потребление, а значит и качество, и технологии.

Производители борются за долю на рынке, за симпатии потребителя и выдают максимум на что способны по минимальным для потребителя ценам. При этом, в обществах без конкуренции, тресты и монополии предлагают неизбалованному потребителю товары и услуги на минимальном уровне качества по максимальным ценам.

Потребитель не имеет возможности «голосовать ногами» и выбирать лучшего на рынке по приемлемой цене, он вынужден довольствоваться тем, что ему предлагает монополист. Последний при этом, не имеет стимулов и мотивации к совершенствованию - итак купят, зачем стараться, зачем снижать цену.

Еще один яркий пример, но уже с другой стороны - пример Советского Союза. Сильный как в научном, так и в технологическом плане СССР, после победы с союзниками во Второй Мировой войне, спустя всего полвека, оказался на грани упадка практически во всех сферах жизнеде- ятельности - от культурно-нравственной до социально-бытовой. Страна-победитель оказалась на грани выживания, запертая в тесных рамках натурального обмена внутри плановой экономики.

В то же время, страны потерпевшие поражение в этой самой разрушительной за всю историю человечества Войне, благодаря международному кредиту и товарно-техническому обмену на принципах конкуренции, довольно быстро, в течение всего пары десятилетий после разгрома, восстановились полностью и обогнали по уровню жизни граждан СССР, даже несмотря на колоссальные природные ресурсы последнего.

Даже с таким бонусом как материальные ресурсы, социально-экономическая модель, предложенная коммунистами, показала свою нежизнеспособность, приведя граждан к нищете и социальной деградации. Люди были в буквальном смысле ввергнуты в нищету, а продукты получали по карточкам. Нередки были случаи, когда граждане самой богатой ресурсами страны - СССР - получали еду в виде гуманитарной помощи от идеологического врага - США.

Очевидно, что при отсутствии нефти и газа, металлов, леса, и другого сырья, подпитывающего такую модель экономического развития, этот режим рухнул бы куда быстрее. Ошибочная экономическая система - это спокойная политическая жизнь в отсутствие политической конкуренции для власти с одной стороны, и плачевный результат для населения - с другой.

Какая же модель правильная и несет для населения расцвет созидательных (не военных) технологий, медицины, образования, культуры и науки? Ответ прост. Достаточно обратиться к истории экономического развития и станет понятно: к ресурсам нужно добавить всего один фактор - конкуренцию.

Всё дело в Конкуренции. Только конкуренция заставляет производителя, в буквальном смысле, становиться лучше, выводя домашнее хозяйство или корпорацию из зоны комфорта. Абстракции про светлое будущее не работают лучше самой простой практической конкуренции. Если ты не лучший - ты теряешь рынок и исчезаешь, на твое место приходит лучший.

Здесь в качестве примера, можно привести поверженные и практически опустошенные после Второй Мировой Войны Германию и Японию, которые уже к концу 60-х годов прошлого века полностью восстановились и превысили рост 
своих экономик до начала Войны, увеличивая Национальный Продукт в каждом следующем десятилетии, догоняя мирового лидера по ВВП США. Также, показала послевоенный рост разрушенная немецкими бомбардировками экономика Великобритании. Этот пример наглядно демонстрирует, что правильная социальноэкономическая установка общества способна эффективно функционировать в любых условиях: от различий в идеологическом аспекте до политических различий - успешные страны объединяет кооперация, кредит, конкуренция.

Отстающие страны объединяет государственное планирование, коллективная собственность, отсутствие внешних инвестиций. Только лишь в последние три десятилетия Индия и Китай, ставшие на путь мировой кредитной кооперации и частного права, стали догонять и обгонять по темпам роста развитые капиталистические страны, начавшие рост ранее, см. рис. № 1, история ВВП США, Великобритании, Японии, Германии, Китая и Индии за триста лет, включая послевоенный период

Более того, в странах с ориентированием на конкуренцию и кредит, помимо страннового роста, наблюдается рост уровня жизни граждан и развития их человеческого потенциала.

Они по сей день удивляют и радуют мир новыми научными открытиями, предлагают товары и услуги самого высокого качества, а уровень жизни граждан этих стран занимает высшие строчки всевозможных рейтингов: от покупательской способности национальных валют (для
Германии сначала марка, а затем и евро) до Индекса развития человеческого потенциала, рис. № 2, данные ООН, 2020 г.

Но даже на примере одной и той же страны, одного и того же народа, но с разными социально-экономическими установками мы видим точно такой же закономерный результат: где конкуренция и кредит, там процветание и рост, где тоталитарный режим, госплан и общественная собственность - там голод, нищета и отсутствие перспектив как в производстве, так и в потреблении. В общем, задержка развития национального масштаба. Достаточно примера Южной и Северной Кореи, рис. № 3.

Только конкуренция и борьба за долю рынка двигают качество товаров и услуг на новые высоты. Никакие идеологические взывания про самосознание производителя или «высокоинтеллектуальные» догмы про достаточность потребления не выдерживают испытание временем.

На производителя товаров и услуг действует только один стимул - материальный. Если ты эффективен, ты сделаешь лучше и за меньшие деньги. Если ты умный, но бедный - доступен кредит на развитие. Если тебя разрушили, но ты готов к кооперации и сотрудничеству - ты вновь будешь сильным, богатым и здоровым.

Таким образом, фактор конкуренции, который является залогом технологического, научного и экономического прогресса как отдельного домашнего хозяйства, так и целых стран, не может в полной мере раскрыться без материальнотехнической базы.

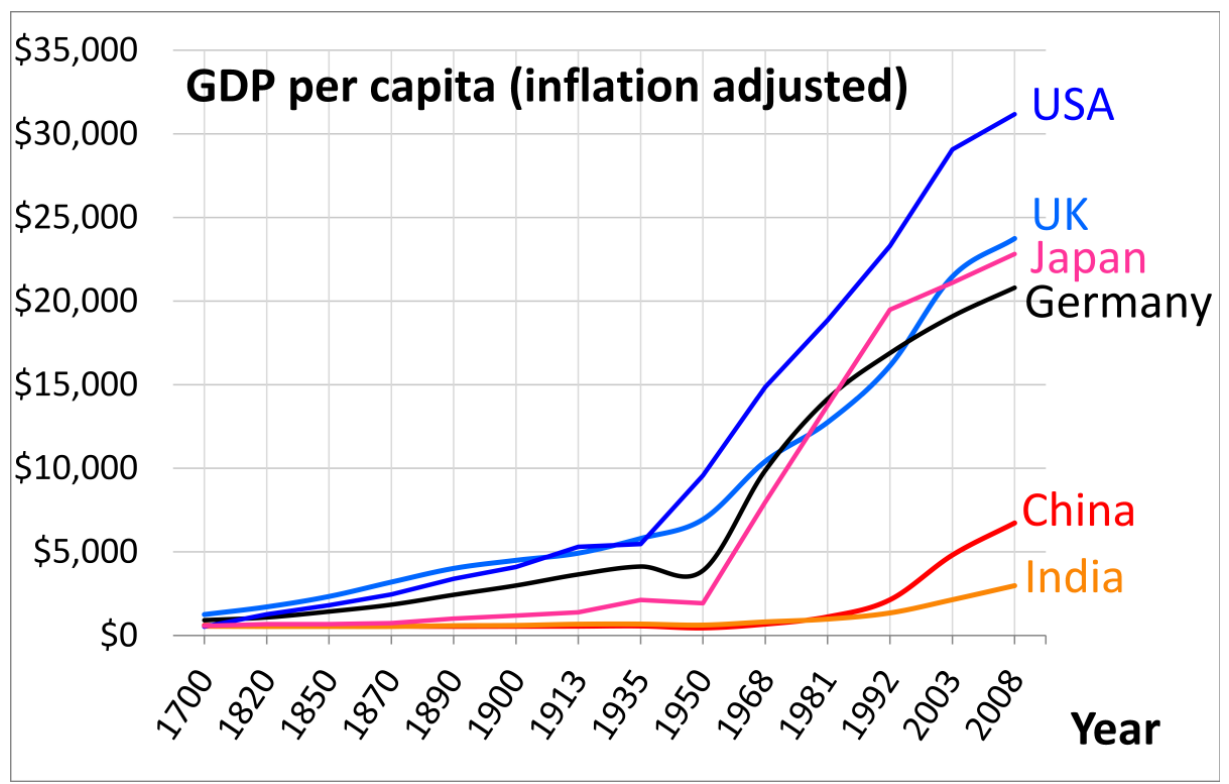

Рисунок 1, История ВВП на душу населения США, Великобритании, Японии, Германии, Китая и Индии за триста лет, включая послевоенный период 


\section{ИНДЕКС РАЗВИТИЯ ЧЕЛОВЕЧЕСКОГО ПОТЕНЦИАЛА}

- В число стран с очень высоким уровнем человеческого развития входят следующие страны:

\begin{tabular}{|c|c|c|c|}
\hline СТРАНЫ & ИРЧП & СТРАНЫ & ИРЧП \\
\hline НОРВЕГИЯ & 0,955 & КАНАДА & 0,911 \\
\hline АВСТРАЛИЯ & 0,938 & РЕСПУБЛИКА КОРЕЯ & 0,909 \\
\hline США & 0,937 & ГОНКОНГ & 0,906 \\
\hline НИДЕРЛАНДЫ & 0,921 & ИСЛАНДИЯ & 0,906 \\
\hline ГЕРМАНИЯ & 0,920 & ДАНИЯ & 0,901 \\
\hline НОВАЯ ЗЕЛАНДИЯ & 0,919 & ИЗРАИЛЬ & 0,900 \\
\hline ИРЛАНДИЯ & 0,916 & БЕЛЬГИЯ & 0,897 \\
\hline ШВЕЦИЯ & 0,916 & АВСТРИЯ & 0,895 \\
\hline ШВЕЙЦАРИЯ & 0,913 & СИНГАПУР & 0,895 \\
\hline ЯПОНИЯ & 0,912 & ФРАНЦИЯ & 0,893 \\
\hline
\end{tabular}

Рисунок 2, ИРЧП, ООН 2020 г.

GDP per capita

Real GDP per capita is measured using US\$, inflation adjusted at prices of 2011. Multiple benchmarks allow cross-country income comparisons.

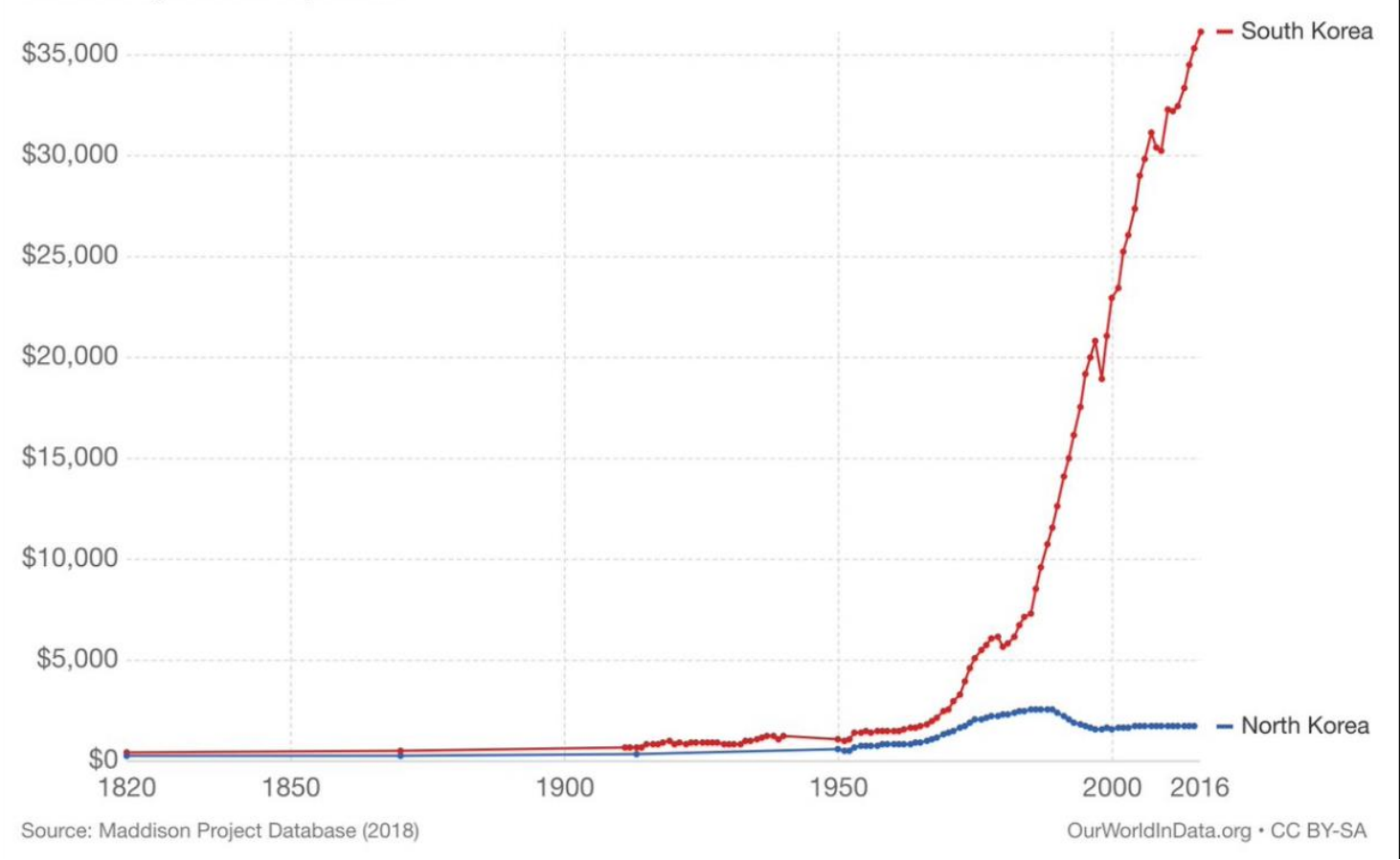

Рисунок 3, Сравнение ВВП на душу населения Северной и Южной Кореи 
Глава 2. КРЕДИТ КАК ТОПЛИВО ДЛЯ РОСТА ИЛИ ЭФФЕКТ ПЕРЕХОДА ОТ ВНУТРЕННЕГО ФИНАНСИРОВАНИЯ К МЕЖДУНАРОДНОМУ

И вот теперь, уместно говорить о ресурсах, понимая, что даже самое богатое ресурсами государство без внутренней конкуренции не способно обеспечить достойное развитие экономики и раскрыть творческий и научный потенциал своих граждан в сравнении с экономиками, где конкуренция является основой производственной культуры общества.

Именно поэтому, мы наблюдали несколько волн «утечек мозгов» из СССР с начала его распада, когда страну покидали лучшие умы. Высококлассные специалисты покидали Родину не только из-за высоких зарплат в развитых экономиках, а в большей мере, видя перспективы для творческого и научного роста, реализации своих способностей, воплощения своих новаторских идей. Удержать дома их не помогла даже колоссальная ресурсная база родной территории и перспективы роста молодой экономики. Однако, ресурсная база в виде полезных природных ископаемых есть не у всех. Что делать странам, у которых нет подобного «стартового капитала»?

Во-первых, переходить к конкурентным отношениям в пределах собственной экономики. И чем раньше, тем лучше. Но и этого недостаточно. В такой ситуации на помощь, в отсутствие стартовых возможностей, приходит институт кредитования. Это второе. Любое эффективное развитие производства и последующего обмена произведенных товаров и услуг, при отсутствие начальной ресурсной базы, возможно только при содействие кредитных организаций и кредита как такового. Кредит и инвестиции вдыхают жизнь в идеи и научные разработки, давая жизнь следующим поколениям на новом, более высоком уровне жизни.

Общества и государства, которые несколько десятилетий назад поняли важность и преимущества международной кооперации и обмена (а в Европе это поняли несколько сотен лет назад), сегодня могут предложить своим гражданам медицинские и образовательные услуги на более высоком уровне, чем страны, добровольно себя изолировавшие и противопоставившие свою изоляционную доктрину всему миру, объединенному международным кредитом и конкуренцией, общей рыночной культурой.

Товары народного потребления и технологии развитых стран, таких как Япония, Герма- ния, США, Норвегия, Швеция и даже маленькая Финляндия и др., как на внутреннем, так и на внешнем рынках, объединенных принципом конкуренции и поддержанные международными инвестициями и кредитом, являются самым предпочтительным товаром даже среди граждан тех стран, которые решили идти «своим путем». Как правило, это тоталитарные режимы, во главе с единственным и неповторимым на все времена лидером.

Иногда, в головах этих граждан ситуация доходит до абсурда - они покупают товары тех стран, которых считают идеологическими врагами. По сути, финансируют своих врагов, вкладывая деньги в их враждебную идеологию, таким образом поощряя ее. Полная каша в головах этих людей, всё время идущих «своим особым путем». Довольно забавное явление в общемировом экономическом аспекте, но грустное в национальном.

Изоляционисты и радикальные консерваторы, охотно покупая товары капиталистических стран, сами финансируют те режимы, с которыми призывают бороться. Отсталые экономики, не способные производить конкурентные товары, вынуждены, под воздействием глобальных процессов, допускать на свои внутренние потребительские рынки товары более высокого качества, невольно демонстрируя преимущества «того» мира.

Получается, что бедные финансируют богатых, ненавидят богатых за их богатство и снова продолжают их финансировать. Мы уже приводили ранее исследование [1] - как рост американского государственного долга затягивает всё новые ресурсы развивающихся экономик, абсорбируя средства у тех, кто не хочет или не может двигаться в русле мировых денежнокредитных отношений.

Доллар США, как мировая кредитная единица, помимо обеспечения национальной валюты за счет роста и объема собственно ВВП США, пользуется спросом со стороны Центральных банков практически всех государств, даже тех, кто помпезно заявляет своим гражданам о дедолларизации, а сами продолжают потихонечку покупать и аккумулировать доллары на своих счетах.

Таким образом, те страны, которые своевременно поняли, что только международное кредитование может практически неограниченно стимулировать национальные экономики, 
успешно совершили переход от плановой экономики, рассчитанной на внутренний спрос к экономике рыночной, рассчитанной на международный рынок. Ярким примером здесь является коммунистический Китай.

Даже несмотря на сомнительную идею всеобщего равенства, коммунистическая партия Китая к концу 20-го века вводит допущение в отношении частной собственности. Крупные системообразующие предприятия по-прежнему остаются государственными, однако появляется институт частного предпринимательства, что было невозможно в Советском Союзе.

Именно мелкий и средний бизнес зародил в Китае мощный средний класс, ставший в последствие куда более значимым драйвером роста всей национальной экономики Китая, нежели бравурные программы экономического развития на съездах партии. Партийным коммунистическим функционерам в самом радужном и светлом сне и присниться не мог такой мощный рост экономики, какой сделал средний класс частных предпринимателей.

Какие бы идеалистические и светлые идеи не выдвигали коммунистические умы и партийные лидеры, простой предприниматель из народа сделал несоизмеримо больше. Теперь Китай самый крупный в мире производитель товаров народного потребления, являясь по сути, мировым сборочным цехом. И отнюдь не благодаря плановой закрытой экономике, ориентированной на внутреннее потребление. Китай поставляет на международные рынки сбыта любые товары в огромном количестве - от игрушек для домашних животных и компьютеров до автомобилей и даже самолетов.

Китай стал экономической супердержавой только благодаря конкурентным рыночным отношениям в стране, умноженным на трудолюбие китайцев, а также институту частной собственности, умноженному на международный кредит.

Еще в середине 20-го века в Китае полностью господствовала коммунистическая идея, исключая любую форму частного права. ВВП Китая в 1952 году был всего 67900 млн. юаней, что в долларах равняется примерно 27,630 миллионов долларов США, а уже в 2019 году ВВП Китая составлял порядка 11 триллионов долларов".

Увеличивая ВВП в среднем на $16 \%$ в год, Китай уже к 2000 году превысил ВВП Италии, в 2007 году достиг ВВП Великобритании, обошел Германию в 2008 году и в 2010 году обогнал Японию. На сегодняшний день Китай - это вторая экономика мира после США., см. рис. 4.

* https://ru.wikipedia.org/wiki/История_ВВП_Китайской_Народной_Республики

\section{ВВП в долларах США}

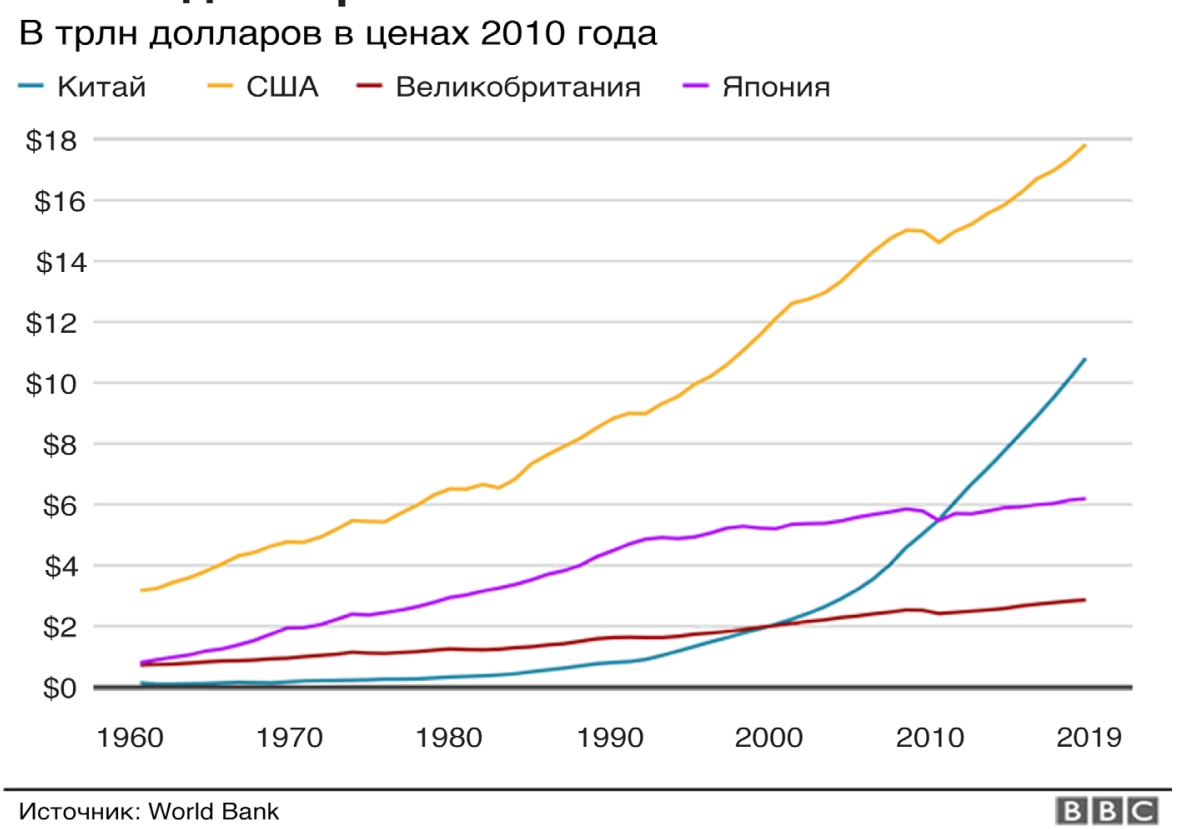

Рисунок 4, Данные World Bank ВВП 


\section{ВЫВОДЫ}

Итак, какие из всего этого можно сделать выводы? Очевидно, что даже при самой эффективной экономике, внутренних ресурсов государства не хватает для того, чтобы конкурировать с транснациональными корпорациями или государственными экономическими объединениями.

Пример: на конец 2020 года капитализация Microsoft, Alphabet, Apple и Amazon составила от 1 до 1.4 трилл. долларов по каждой компании, см. рис. № 5.

На конец июля 2021 года рыночная капитализация одной только Microsoft составила порядка 1,8 триллиона долларов, в то время как ВВП России в 2020 году, по данным Росстата, составил около 106,606 млрд. рублей или на конец июля 2021 года, около 1,42 триллиона долларов по курсу 75 рублей за доллар при прогнозной оценке Минфина России по 2021 году - в районе 1,7 триллиона долларов.

Как видно из примера выше, объединение даже на уровне корпорации может конкурировать, а иногда и превосходить бюджеты даже очень крупных государств.

Так же, как и в примере с неограниченными ресурсами, но в замкнутой на саму себя эконо- мике, не достаточно иметь неограниченные ресурсы при тупиковой ветви экономического развития в отсутствие конкуренции.

СССР, в отличие от Китая, обладал практически неисчерпаемыми запасами полезных ископаемых, однако это не помогло коммунистическому режиму Советского Союза в отсутствие частного права, международных кредитных отношений и свободной конкуренции выйти в лидеры по темпам роста экономики и производству, как это удалось Китаю, который понял, что двигатель экономики - это средний класс, финансируемый международным кредитом, см. Рис. № 6

По нашим оценкам государственный долг Китая к концу 2021 года достигнет 69\% ВВП.

Разумеется, при росте государственного долга к ВВП стоит учитывать, что Китай по Паритету Покупательной Способности уже с 2014 года вышел в лидеры, обогнав США. Растет благосостояние китайских граждан, растет уровень жизни населения - рост экономики Китая продолжается, рис. № 7 когда Китай обогнал США по ППС, источник МВФ.

В основе государственного строя любой развитой капиталистической страны лежат социальные основы общества - Норвегия, Япония,

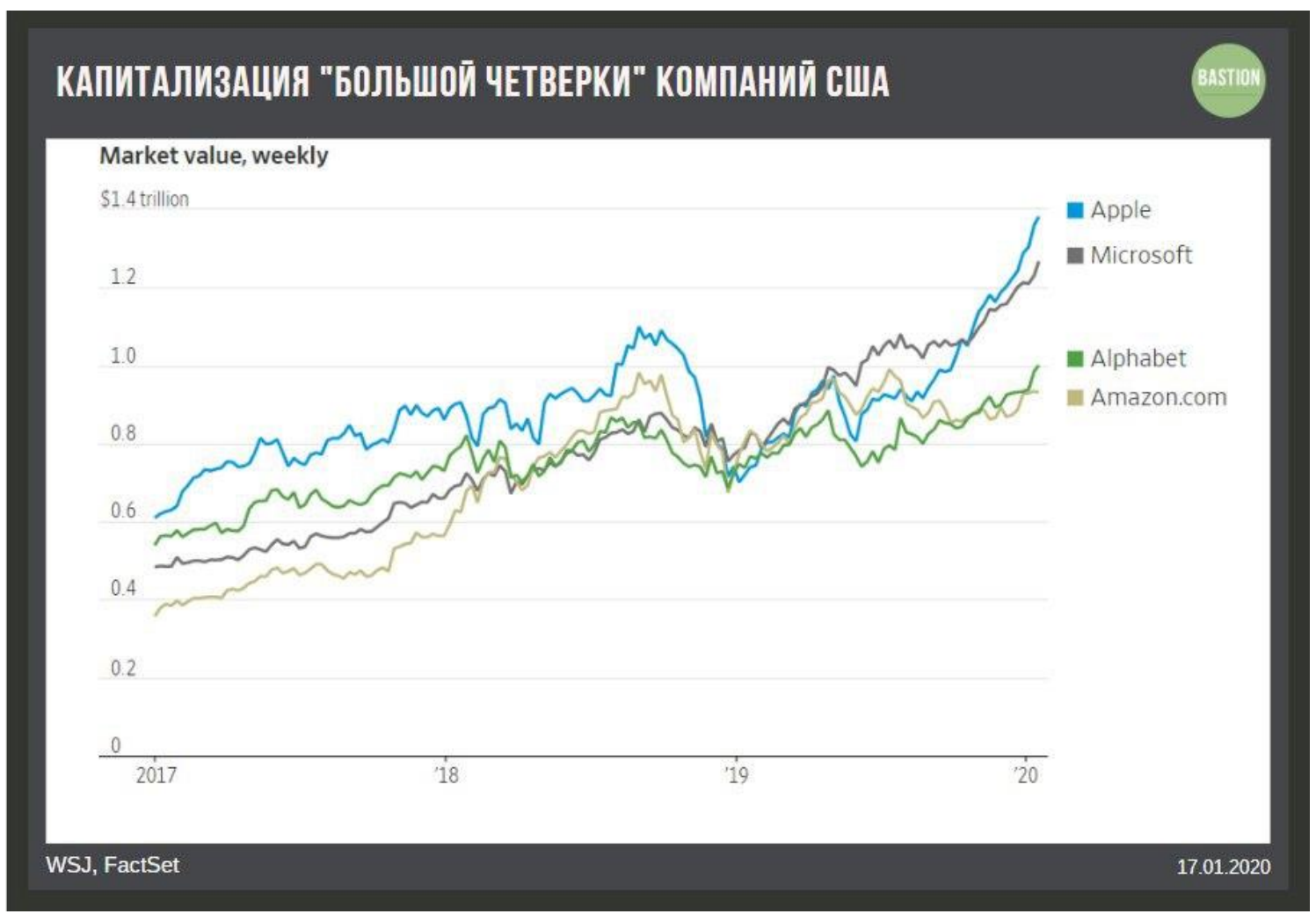

Рисунок 5, «Большая четверка» США 


\section{Госдолг Китая в \% к ВВП (номинальный)}

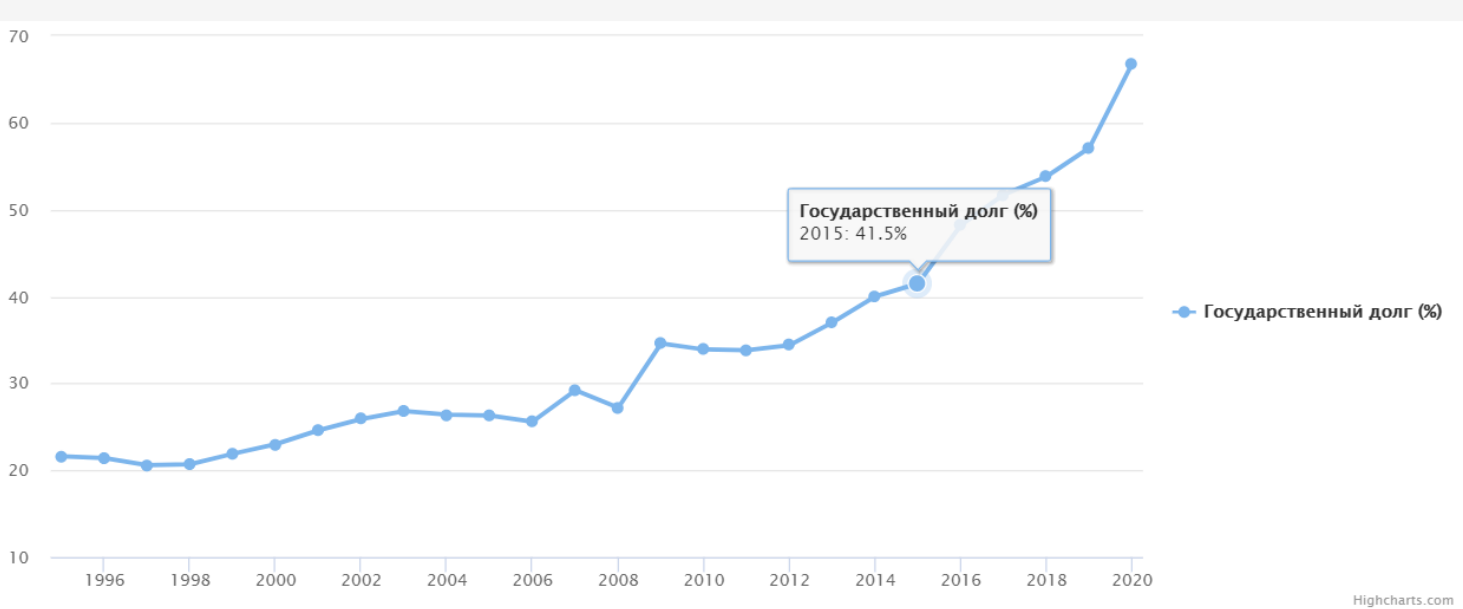

Рисунок 6, Госдолг Китая 1995-2020 гг.

\section{Как Китай обогнал США по ВВП по ППС}

\section{ВВП Китая в текущих ценах, \$трлн}

ВВП США в текущих ценах, \$трлн

ВВП по паритету понупательной способности Китая, \$трлн

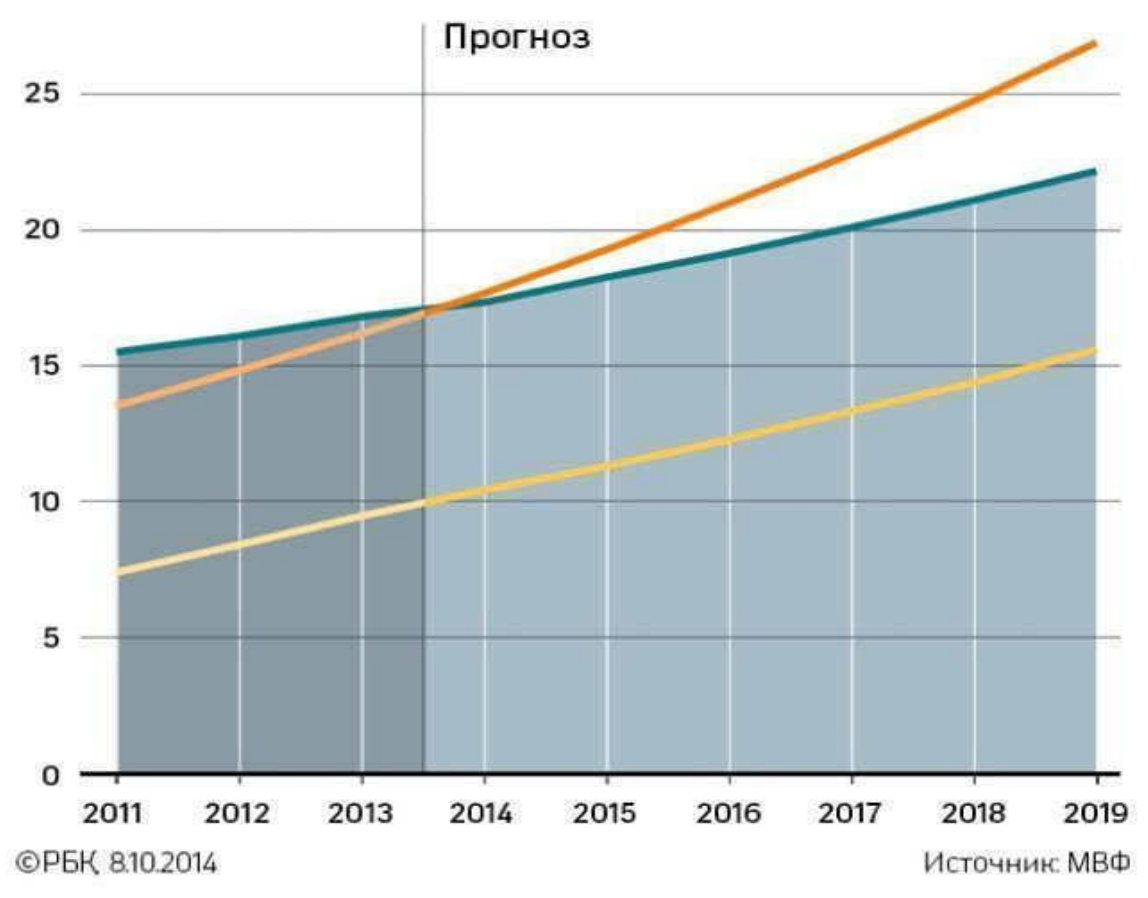

Рисунок 7, ВВП Китая и США по ППС 
Германия и т.д. Они прекрасно работают в условиях жесткой рыночной конкуренции. И даже в коммунистических режимах, при наличии института частной собственности и кредита, возможен устойчивый рост благосостояния - яркий пример Китай.

В то же время, при практически неограниченных производственных ресурсах, огромных территориальных преимуществах (транзит Европа-Азия) в отсутствие конкуренции и внешнего финансирования, устойчивый рост благосостояния населения на мировом уровне невозможен - яркий и достаточный пример СССР.

Современной России, как и любому другому государству в наши дни, для устойчиво- го роста уровня социально-бытовых условий граждан и развития человеческого потенциала, необходимо научно-техническое, финансовоинвестиционное и культурное сотрудничество в мировом масштабе, гарантия соблюдения частного права граждан по международным стандартам.

Ни одно общество, вне зависимости от идеологии или государственного уклада, не может устойчиво развиваться без института частной собственности как основы конкуренции во всех аспектах жизни общества. А экономический рост государства невозможен без частных инвестиций и международного кредита.

\section{Библиографический список}

1. Пушкарев Д.В. Госдолг США - чья это проблема? // Вопросы устойчивого развития общества. 2021 . № 6 Available at: http://adm.nauka20-35.ru/Files/ArticleFiles/91ac0677-6cda-4c7a-9c78-471601922af5.pdf. DOI: 10.34755/IROK.2021.77.82.164

2. Росстат представляет первую оценку ВВП за 2020 год. Федеральная служба государственной статистики. Available at: https://rosstat.gov.ru/folder/313/document/113015

3. Стиглиц Дж., Великое разделение. Неравенство в обществе, или что делать оставшимся 99\% населения? [The Great Divide: Unequal Societies and What We Can Do About Them.]. Эксмо, 2016. 480 с. ISBN 978-5-69983649-9

4. Hightcarts.com Available at: https://www.highcharts.com/demo/stock/data-grouping

5. Frontier Market Debt Monitor: Double - edged sword. The institute of International Finance. Available at: https:// www.iif.com

6. United Nations Department of Economic and Social Affairs. Available at: https://www.un-ilibrary.org/search?valu e1=United+Nations+Department+of+Economic+and+Social+Affairs \&option1=author \&noRedirect=true 